\title{
Optimization of the treatment of carbon monoxide-polluted air in biofilters
}

Yaomin Jin, Ling Guo, María C. Veiga, Christian Kennes

Chemosphere Volume 74, Issue 2, January 2009, Pages 332-337

DOI: 10.1016/j.chemosphere.2008.10.001

\begin{abstract}
This work is the first extensive study on the removal of carbon monoxide from polluted air in biofilters. It compares the performance of two packing materials, namely lava rock alone and a mixture of peat and lava rock. The results show that the biofilter packed with the mixture of peat and lava rock performed much better than the other one. The effect of operating conditions as, among others, the inlet concentration and the empty bed residence time (EBRT) were studied. A maximum elimination capacity of $33 \mathrm{~g} \mathrm{~m}^{-3} \mathrm{~h}^{-1}$ was obtained with the mixed packing with more than $85 \%$ removal efficiency at EBRT of 3 min or more. Somewhat lower performances were reached at shorter EBRT. The results presented here suggest that the mixture of lava rock and peat, subject to further optimization, offers potential for the biological removal of $\mathrm{CO}$ from polluted gas streams.
\end{abstract}

\section{Keywords}

Carbon monoxide; Biofilter; Aerobic; Packing material; Waste gases

\section{Introduction}

Carbon monoxide plays an important role in controlling tropospheric chemistry. The presence of $\mathrm{CO}$ in the atmosphere affects the ozone concentration, which has a significant impact on climate, human health, and plants (Peng et al., 2007). CO is categorized as a priority pollutant by the US Environmental Protection Agency. It aggravates coronary artery disease, may impair cerebrovascular functions, increases hospitalizations for acute respiratory conditions, reduces birth weights for exposed mothers, and can lead to death. Estimates of annual global emissions of CO vary from 2040 to $3315 \mathrm{Tg}$ (Tilley and Mentzer, 2006). Best estimates place anthropogenic contributions at two-thirds of the total, with automotive emissions contributing the most. Sources of CO emissions include fossil fuel combustion, biomass burning, atmospheric oxidation of non-methane hydrocarbons, methane oxidation, and vegetative gas exchanges.

Concern for environmental and health issues coupled with stringent $\mathrm{CO}$ emission standards indicate a need for the development of efficient low-cost CO reduction technologies. Conventional CO treatment technologies include selective catalytic oxidation using noble metals such as $\mathrm{Au}, \mathrm{Pt}, \mathrm{Ru}$ and $\mathrm{Rh}$, as well as $\mathrm{UV}$, and photocatalytic technologies ( $\mathrm{Li}$ et al., 2003). All these technologies are very expensive. Biofiltration is a promising technology involving the flow of a polluted air stream first 
humidified and then vented through a bed packed with solid media (e.g., compost, peat, soil, wood chips, or inert packing materials) containing microorganisms that are able to degrade pollutants (Kennes and Veiga, 2001 and Kennes and Veiga, 2004). Biofiltration is a viable and potentially cost-effective alternative for treating high flow rates air streams with low-concentration pollutants. The low operating/energy costs result from the utilization of microbial oxidation under ambient conditions instead of oxidation by thermal or chemical means. Biofiltration is a multi-step process involving the diffusion of the gaseous pollutants and oxygen from air to the aqueous biofilm. Microorganisms in the biofilm metabolize the pollutants into $\mathrm{CO}_{2}, \mathrm{H}_{2} \mathrm{O}$, new biomass, and sometimes other harmless end products (Leson and Winer, 1991, van Groenestijn and Hesselink, 1993, Kennes and Thalasso, 1998 and Kennes and Veiga, 2001). The effectiveness of the biofilter for the treatment of waste gases largely depends upon the solubility of the compounds in the liquid layer of the biofilm. When hydrophobic compounds are degraded in biofilters, the process is generally limited by the mass transport of the sparingly soluble compounds (Ottengraf and van den Oever, 1983 and Jin et al., 2005a). Although traditionally most widely used for odor control at wastewater treatment plants and composting facilities, biofilters are now also increasingly applied to treat industrial air emissions (Kennes and Veiga, 2001).

$\mathrm{CO}$ is metabolized by a wide variety of microorganisms such as methanotrophs, ammonia oxidizers, carboxydotrophs, oligotrophic bacteria, fungi, and algae. A sharp division exists between aerobic and anaerobic species, as they contain fundamentally different enzyme systems for CO biotransformation (Meyer and Schlegel, 1983). Aerobic CO oxidizing bacteria may be divided into two groups depending on their metabolism, i.e., metabolic degradation, in which $\mathrm{CO}$ oxidation provides energy for growth, and co-metabolic degradation, in which CO is used as pseudo-substrate for the enzyme system, but does not provide any nutritional value (Colby et al., 1985). The latter is observed during aerobic CO oxidation by methane oxidizing bacteria employing the methane monooxygenase complex, which is rather unspecific with respect to its substrate (Daniels et al., 1977 and Higgins et al., 1980). Aerobic metabolic CO oxidizing bacteria, also known as carboxydotrophs, oxidize $\mathrm{CO}$ with $\mathrm{O}_{2}$ as terminal electron acceptor and use the released energy during this process for growth.

However, basically no exhaustive previous studies have been published on CO removal from polluted air in biofilters. Robra et al. (1997) enriched bacteria capable of eliminating low concentrations of $\mathrm{CO}, \mathrm{NO}$, and $\mathrm{NO}_{2}$ in a mineral medium in the absence of other nitrogen compounds in a laboratory-scale bioreactor packed with light expanded clay aggregates. Later, a pilot plant biofilter was built to treat polluted air of a road tunnel in Austria. The $55 \mathrm{~L}$ trickling filter exhibited good performance over $2 \mathrm{y}$ of experimentation. At gas residence times ranging from 7.5 to $11 \mathrm{~s}$, maximum removal efficiencies of $90 \% \mathrm{CO}, 15-20 \% \mathrm{NO}, 95 \% \mathrm{NO}_{2}$, and $50-75 \%$ non-methane volatile organic compounds were obtained. The carboxydotrophic biomass was claimed to reach a CO elimination capacity of $10 \mathrm{~g} \mathrm{~m}^{-3} \mathrm{~h}^{-1}$ (Robra et al., 1997).

Recently it was observed in our laboratory that CO removal from waste gases was possible by inoculating adapted mixed cultures in a lava rock packed biofilter treating an industrial waste gas mixture containing formaldehyde, methanol, dimethylether, and CO (Prado et al., 2006 and Prado et al., 2008). However, similar bioreactors inoculated with a pure culture of the efficient CO-degrader Oligotropha carboxidovorans OM5 were not successful, as the strain was quickly overgrown by other invading organisms ( 
Prado et al., 2008). Only low CO removals were achieved and process optimization was still needed.

The purpose of the present research was to check the feasibility of using gas-phase biofilters to efficiently treat CO-polluted air. Two bioreactor packing materials that exhibit long-term stability and allow biological carbon dioxide removal with reduced back pressure were considered, namely lava rock alone and a mixture of peat and lava rock. The maximal performance of the biofilters was compared for these two packing materials under different operating conditions. The influence of variable loads was studied by feeding different inlet concentrations and operating at different empty bed residence times.

\section{Material and methods}

\subsection{Media composition}

The nutrient solution employed during the study contained (in $\mathrm{g} \mathrm{L}^{-1}$ ): $\mathrm{MgSO}_{4} \cdot 7 \mathrm{H}_{2} \mathrm{O}$, $0.12, \mathrm{KH}_{2} \mathrm{PO}_{4}, 0.25,\left(\mathrm{NH}_{4}\right)_{2} \mathrm{SO}_{4}, 1.18, \mathrm{NaCl}, 1.00, \mathrm{NH}_{4} \mathrm{Cl}, 0.96$. The culture medium was autoclaved at $120^{\circ} \mathrm{C}$ for 20 min before adding filter-sterilized solutions of vitamins and trace minerals. The composition of the vitamins solution was (in $\mathrm{g} \mathrm{L}^{-1}$ ): 0.2 thiamine $\cdot \mathrm{HCl}, 0.1$ riboflavin, 1.0 nicotinic acid, 2.0 Ca-pantothenate, 0.1 biotin, 0.1 thioctic acid, 0.1 folic acid, and 0.25 pyridoxine $\mathrm{HCl}$. The composition of the trace minerals solution was (in mg L ${ }^{-1}$ ): $120 \mathrm{FeCl}_{3}, 50 \mathrm{H}_{3} \mathrm{BO}_{3}, 10 \mathrm{CuSO}_{4} \cdot 5 \mathrm{H}_{2} \mathrm{O}, 10 \mathrm{KI}, 45$ $\mathrm{MnSO}_{4} \cdot \mathrm{H}_{2} \mathrm{O}, 20 \mathrm{Na}_{2} \mathrm{MoO}_{4} \cdot 2 \mathrm{H}_{2} \mathrm{O}, 75 \mathrm{ZnSO}_{4} \cdot 7 \mathrm{H}_{2} \mathrm{O}, 50 \mathrm{CoCl}_{2} \cdot 6 \mathrm{H}_{2} \mathrm{O}, 20 \mathrm{KAl}\left(\mathrm{SO}_{4}\right)_{2}$ - $12 \mathrm{H}_{2} \mathrm{O}$, and $13.25 \mathrm{CaCl}_{2} \cdot 2 \mathrm{H}_{2} \mathrm{O} .100 \mathrm{~mL}$ aqueous mineral medium was delivered every other day over the packed bed in order to provide fresh nutrients and to remove accumulated metabolite compounds, if any.

\subsection{Experimental setup}

The schematic of the biofilter used in this study is shown in Fig. 1. It is a cylindrical packed bed reactor made of glass, $80 \mathrm{~mm}$ in diameter and $500 \mathrm{~mm}$ in height. The active height of the packed column, filled with either lava rock or a mixture of lava rock and peat, were 300 and $450 \mathrm{~mm}$, respectively, corresponding to a total reactive bed volume of either 1 or $1.5 \mathrm{~L}$, respectively. All fittings, connections and tubings were made of Teflon. The biofilter was fed through its top with a mixture of humidified air and CO, in the desired proportions. The Tedlar bag filled with pure $\mathrm{CO}$ was supplied from a pressurized cylinder. The inlet concentration of $\mathrm{CO}$ was maintained in the range of 24$8830 \mathrm{mg} \mathrm{m}^{-3}$ by adjusting the rotation speed of a compact reglo peristaltic pump, model ISM829, MS-2/08 (ISMATEC SA, Glattbrugg, Switzerland) with a tube connected between the bag and silicone tube. In Section 3.1, the gas flow rate was kept at $42 \mathrm{~L} \mathrm{~h}^{-1}$, which implies an empty bed residence time (EBRT) of 85 s. In Section 3.2, the gas flow rate ranged from 7.5 to $180 \mathrm{~L} \mathrm{~h}^{-1}$, corresponding to residence times ranging from 0.5 to $12 \mathrm{~min}$. 


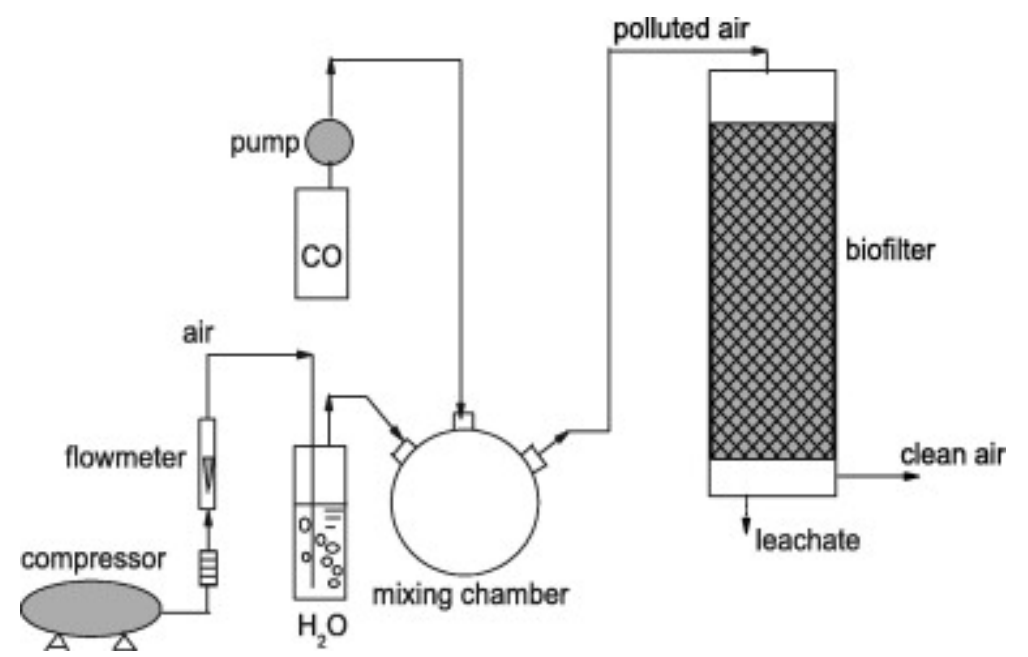

Fig. 1. Schematic of the biofilter treating carbon monoxide.

In choosing packing materials, our concern was to provide a large surface area for microbial adhesion and efficient mass transfer along with a minimal pressure drop along the bioreactor. Microbial compatibility, low cost, and availability were additional considerations. One of the packing materials tested was lava rock. The properties of lava rock are as follows: density, $867 \mathrm{~kg} \mathrm{~m}^{-3}$; porosity, 50\%; size, 4-10 mm. After the first experimental phase, approximately $75 \%$ by weight of peat was mixed with lava rock as packing material. The main characteristics of peat are as follows: $\mathrm{pH}, 5.5-6.5$, water content, 50-60\%, Nitrogen content, $150-250 \mathrm{mg} \mathrm{kg}^{-1}, \mathrm{P}_{2} \mathrm{O}_{5}$ content, 150 $250 \mathrm{mg} \mathrm{kg}^{-1}, \mathrm{~K}_{2} \mathrm{O}$ content, 300-500 $\mathrm{mg} \mathrm{kg}^{-1}$, and organic material, $>70 \%$.

\subsection{Inoculum for the biofilter}

In Section 3.1, the reactor was first inoculated with $250 \mathrm{~mL}$ aerobic activated sludge obtained from the wastewater treatment plant of a synthetic resin-producing factory. It was later also inoculated with a pure culture of the CO-degrader O. carboxidovorans as described in Section 3.

In order to obtain an efficient inoculum for Section 3.2, activated sludge containing a CO degrading consortium was acclimated to CO-polluted air in a flask beforehand. Besides, leachate from the former experimental bioreactor was seeded into fresh nutrient medium and pure $\mathrm{CO}$ gas was injected into the bottle whenever necessary. The flasks were incubated at $30{ }^{\circ} \mathrm{C}$ with a shaking speed of $120 \mathrm{rpm}$ and were then used to inoculate the bioreactor.

\subsection{Analytical methods}

Gas phase concentrations of carbon monoxide in the biofilters were measured by gas chromatography using a Hewlett-Packard 6890 gas chromatograph (GC) equipped with a thermal conductivity detector. The GC was equipped with a $15 \mathrm{~m}$ HP-PLOT Molecular Sieve 5A column (internal diameter $0.53 \mathrm{~mm}$, film thickness $50 \mu \mathrm{m}$ ). For carbon monoxide determination, an initial oven temperature of $50{ }^{\circ} \mathrm{C}$ was maintained for $5 \mathrm{~min}$, followed by a $20^{\circ} \mathrm{C} \mathrm{min}{ }^{-1}$ increase for $2 \mathrm{~min}$, and a final period of constant temperature at $90^{\circ} \mathrm{C}$. The temperatures of the injector and the detector were kept at $150{ }^{\circ} \mathrm{C}$. 
The chemical composition of the filter bed was investigated after $300 \mathrm{~d}$ of operation. Samples were taken at different heights in the filter bed and analyzed for $\mathrm{pH}$ from time to time. The $\mathrm{pH}$ was measured after suspending $3-4 \mathrm{~g}$ of packing sample in demineralized water $(1: 5 \mathrm{w} / \mathrm{v})$ and vigorously stirring on a magnetic stirrer (in quadruplicate) for $15 \mathrm{~min}$. The $\mathrm{pH}$ was measured with a Crison $\mathrm{pH}$-meter 507, using a combined glass electrode. The $\mathrm{pH}$ of the leachate was also measured regularly.

Samples of colonized packing material exposed to CO were prepared for observations under the electron microscope according to a standard procedure as reported previously (Jin et al., 2005b). Examination was performed with a JEOL JSM-6400 SEM working at a voltage of $20 \mathrm{kV}$ and a working distance of $15 \mathrm{~mm}$, and with Oxford Instruments EDX equipment. Samples were photographed extensively to ensure that representative images of the filter bed had been taken.

\section{Results and discussion}

\subsection{Experiment 1}

\subsubsection{Performance of the lava rock packed biofilter}

In this experiment, lava rock alone was used as packing material. The inlet concentration of CO was maintained in the range of $24-1981 \mathrm{mg} \mathrm{m}^{-3}$, with a gas flow rate of $42 \mathrm{~L} \mathrm{~h}^{-1}$, which implies an EBRT of $85 \mathrm{~s}$. During the first $56 \mathrm{~d}$ of operation, the average inlet concentration of CO was kept around $200 \mathrm{mg} \mathrm{m}^{-3}$, and the removal efficiency was around 20\%. Afterwards, the removal efficiency improved slightly and the maximum value occasionally reached $85 \%$ (Fig. 2). Throughout experiment 1 , the elimination capacity was close to $2 \mathrm{~g} \mathrm{~m}^{-3} \mathrm{~h}^{-1}$, and the corresponding average removal efficiency was roughly $21 \%$.

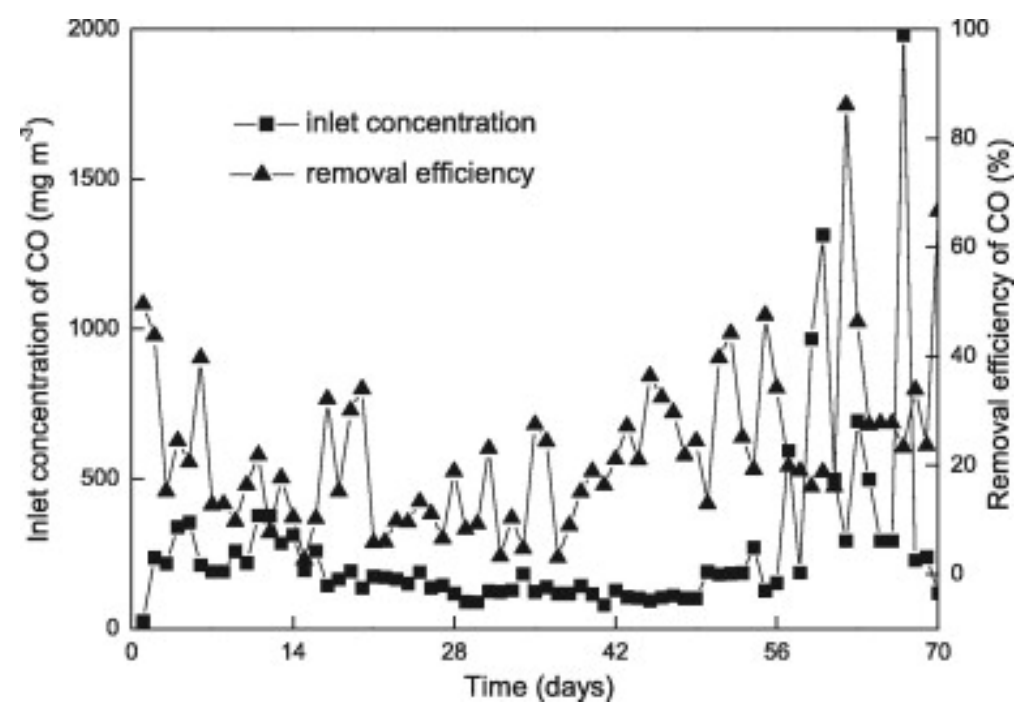

Fig. 2. Inlet concentration and removal efficiency of CO in Section 3.1, with lava rock as a packing material.

In an attempt to improve the performance of the biofilter and because of the poor biomass growth, the reactor was reinoculated on day 6 and on day 20 with $250 \mathrm{~mL}$ of a pure culture of an efficient CO degrading O. carboxidovorans strain. Nevertheless, the removal of CO did not improve after several weeks' operation. The results can be 
explained, among others, by the fact that lava rock may not be the most suitable carrier material for the growth of the inoculated biomass, as was also recently observed for the Oligotropha strain that does poorly attach on a support as lava rock ( Prado et al., 2008). On the other hand, mass transfer limitation due to the low Henry's constant of $\mathrm{CO}\left({ }_{\mathrm{H} \text { inv }}^{\mathrm{co}}={ }^{43} \mathrm{KH}\right.$,invcc=43 dimensionless gas-concentration/aqueous-concentration $)$ played a significant role.

\subsection{Experiment 2}

\subsubsection{Abiotic removal of $\mathrm{CO}$ in a peat-lava rock packed biofilter}

The removal of $\mathrm{CO}$ in a biofilter involves both biological and physical mechanisms. Adsorption studies were conducted to evaluate CO removal in an autoclaved peat and lava rock packed biofilter. Before packing the reactor, the packing material was autoclaved for $20 \mathrm{~min}$ at $120^{\circ} \mathrm{C}$. CO was then fed at a concentration of $1120 \mathrm{mg} \mathrm{m}^{-3}$. After $2 \mathrm{~h}$ operation, an elimination efficiency below $0.5 \%$ was obtained, and after one day no further elimination was observed. The results suggested that abiotic uptake of $\mathrm{CO}$ is negligible.

\subsubsection{Start-up of the biofilter with the new packing material}

In a new attempt to improve the removal of $\mathrm{CO}$, the biofilter was repacked with a mixture of lava rock and peat. The biofilter was restarted with an inlet CO concentration of $2000 \mathrm{mg} \mathrm{m}^{-3}$. The biodegradation of CO resumed immediately upon starting feeding polluted air. The removal efficiency remained constant around 10\% over the first $3 \mathrm{~d}$, and then started to increase as the inlet concentration was reduced to $1000 \mathrm{mg} \mathrm{m}^{-3}$. It indicates that the CO-degraders can adapt to the new packing environment and start to biodegrade the pollutant almost immediately. Peat usually is colonized by large numbers of indigenous diverse microorganisms (Küster and Locci, 1963 and Mériaux et al., 2006). With this new packing, 60\% CO removal was reached within $9 \mathrm{~d}$ after restartup, and in less than $15 \mathrm{~d}$, a quasi-steady state and about $90 \%$ removal of CO were achieved while maintaining the inlet concentration around $1000 \mathrm{mg} \mathrm{m}^{-3}$, at a gas flow rate of $15 \mathrm{~L} \mathrm{~h}^{-1}$, corresponding to an EBRT of $6 \mathrm{~min}$ (Fig. 3). The results indicated that the mixture of lava rock and peat packed biofilter performed much better than the former bioreactor. It maybe caused by the insufficient amount of specific $\mathrm{CO}$ degrading microorganisms in the lava rock packed bioreactor. Besides, biomass growth and activity rely on the amount of available nutrients, which are absent in inert carriers such as lava rock. Conversely, peat already naturally contains some nutrients as nitrogen, phosphorus, and many other elements needed in trace concentrations by the microorganisms. 


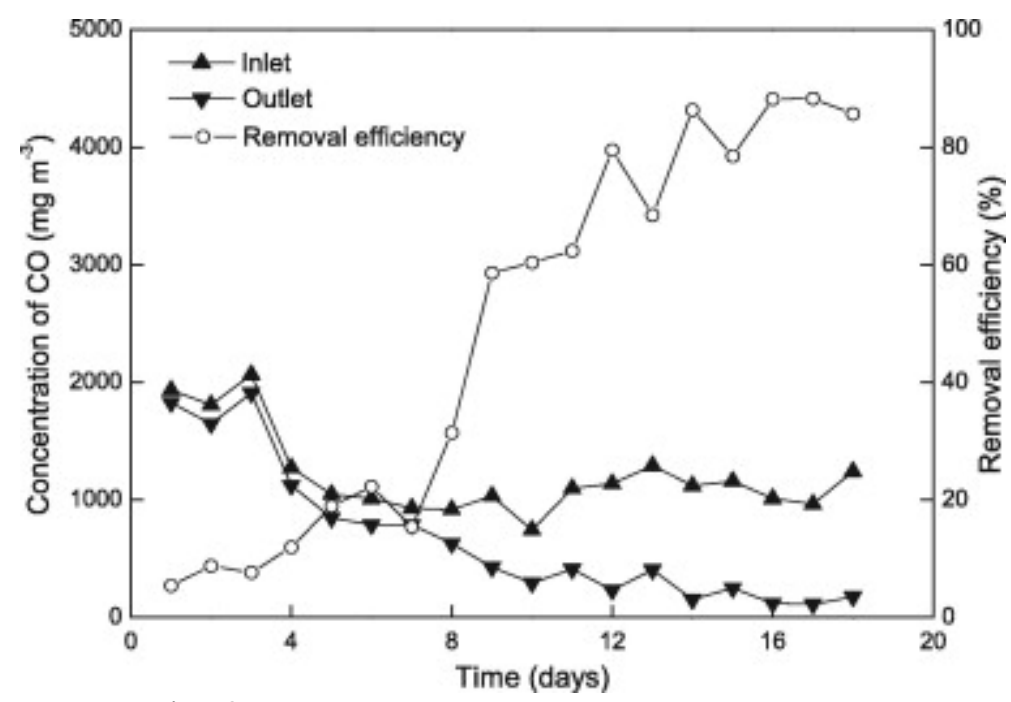

Fig. 3. Startup of the mixture of lava rock and peat packed biofilter.

\subsubsection{Effect of the residence time on $\mathrm{CO}$ removal}

Pollutant removal in the biofilter takes place in two steps. First, CO is transferred from the gas phase and diffuses into the liquid phase or biofilm; then $\mathrm{CO}$ is metabolized by the carboxydotrophic microorganisms. The effect of the retention time on $\mathrm{CO}$ removal was studied by feeding $785 \mathrm{mg} \mathrm{CO} \mathrm{m}^{-3}$ to the bioreactor while applying variable gas flow rates. As shown in Fig. 4, the $\mathrm{CO}$ removal efficiency decreased progressively when decreasing the residence time (i.e., increasing the gas flow rate). The CO removal efficiency dropped from $100 \%$ to $85 \%$ when the gas retention time was decreased from 150 to $120 \mathrm{~s}$. Moreover, below $103 \mathrm{~s}$, the CO removal efficiency in this biofilter dropped down below $80 \%$, and it decreased dramatically with a further decrease in the gas residence time. When it was reduced down to $21 \mathrm{~s}$, the removal efficiency was only $11 \%$. The overall removal process was considerably limited by the CO diffusion rate in the liquid/biofilm. This is due to insufficient time for $\mathrm{CO}$ to diffuse from the bulk gas phase into the biofilm at a low gas residence time. On the other hand, complete removal efficiencies of CO were achieved when the retention time was longer than $144 \mathrm{~s}$. Therefore, there is no additional benefit in terms of removal efficiency at a gas residence time longer than $2.5 \mathrm{~min}$ when the inlet concentration is $785 \mathrm{mg} \mathrm{m}^{-3}$. This also implies that there should be an optimum gas retention time to meet both the requirements of achieving a high removal efficiency and spending less capital on operating costs. Although EBRT below 1 min are most commonly applied in gas-phase biofiltration (Kennes and Veiga, 2001); higher residence times may sometimes be required for recalcitrant and poorly water soluble pollutants as, for example, chlorinated volatile organic compounds (Kennes et al., 2006), NO (Jin et al., 2005a), or CO, as in the present case, in order to achieve acceptable removals. To be cost-effective, the EBRT should, however, as far as possible be reduced below 2 min. 


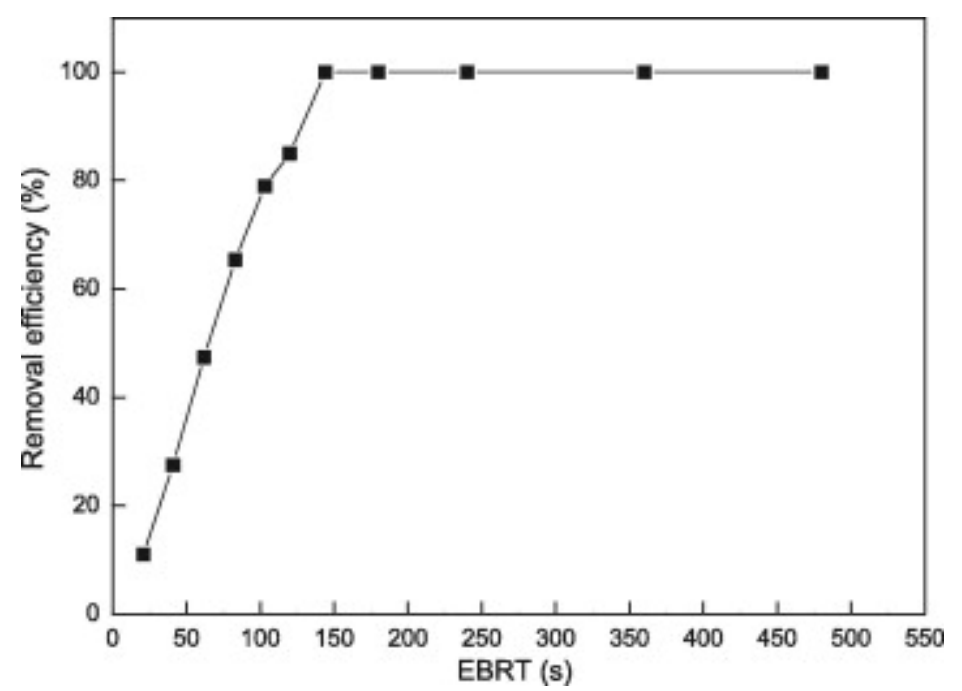

Fig. 4. Effect of the empty bed retention time on CO removal efficiency at a feed concentration of $785 \mathrm{mg} \mathrm{m}^{-3}$.

\subsubsection{Effect of the inlet loading rate and inlet concentration}

Loading can be increased either from an increase in superficial gas velocity at a constant concentration of the pollutant or from an increase in pollutant concentration at a given gas velocity. Different loads were applied by modifying either parameter. Fig. 5 shows the elimination capacities versus the inlet loading rates of CO. The diagonal line represents 100\% CO removal. These data include the results of all the experiments performed on the biofilter under the employed operating conditions for CO inlet concentration and gas flow rate at a quasi-steady state. At a gas flow rate of $7.5 \mathrm{~L} \mathrm{~h}^{-1}$, at low inlet loading rates, the removal rate of $\mathrm{CO}$ increased proportionally with increasing the initial CO inlet loading rate since the amount of CO transported from the air stream to the biofilm increased with increasing inlet loads from 0 to $30 \mathrm{~g} \mathrm{~m}^{-3} \mathrm{~h}^{-1}$. At steady state a load of up to $30 \mathrm{~g} \mathrm{~m}^{-3} \mathrm{~h}^{-1}$ resulted in a $100 \%$ removal of CO from the gas phase. This removal rate exceeds those reported before by a factor of two or more (Robra et al., 1997 and Prado et al., 2008). At such higher loads, the average elimination capacity became relatively constant at about $32 \mathrm{~g} \mathrm{~m}^{-3} \mathrm{~h}^{-1}$ when the inlet loadings were greater than 30 and smaller than $62 \mathrm{~g} \mathrm{~m}^{-3} \mathrm{~h}^{-1}$. The removal efficiency gradually decreased from about $100 \%$ to $14 \%$ when the loading rate was increased from 30 to $95 \mathrm{~g} \mathrm{~m}^{-3} \mathrm{~h}^{-1}$. The results indicate that the activity of microbes in the biofilm reached a maximum. For the higher gas flow rate of $15 \mathrm{~L} \mathrm{~h}^{-1}$, Fig. 5 reveals a similar trend of variation of elimination capacity versus inlet loading rate as for a gas flow rate of $7.5 \mathrm{~L} \mathrm{~h}^{-1}$, except that the maximum elimination capacity for $15 \mathrm{~L} \mathrm{~h}^{-1}$ is a little larger, i.e., $33 \mathrm{~g} \mathrm{~m}^{-3} \mathrm{~h}^{-1}$ for inlet loading rates varying from 26 to $88 \mathrm{~g} \mathrm{~m}^{-3} \mathrm{~h}^{-1}$. Similarly, at a gas flow rate of $30 \mathrm{~L} \mathrm{~h}^{-1}$, the removal of CO decreases from $77 \%$ to $24 \%$ for inlet loading rates ranging from 39.2 to $75.3 \mathrm{~g} \mathrm{~m}^{-3} \mathrm{~h}^{-1}$. The highest elimination capacity of the biofilter reached in this experiment was about $33 \mathrm{~g} \mathrm{~m}^{-3} \mathrm{~h}^{-1}$ (Fig. 5). 


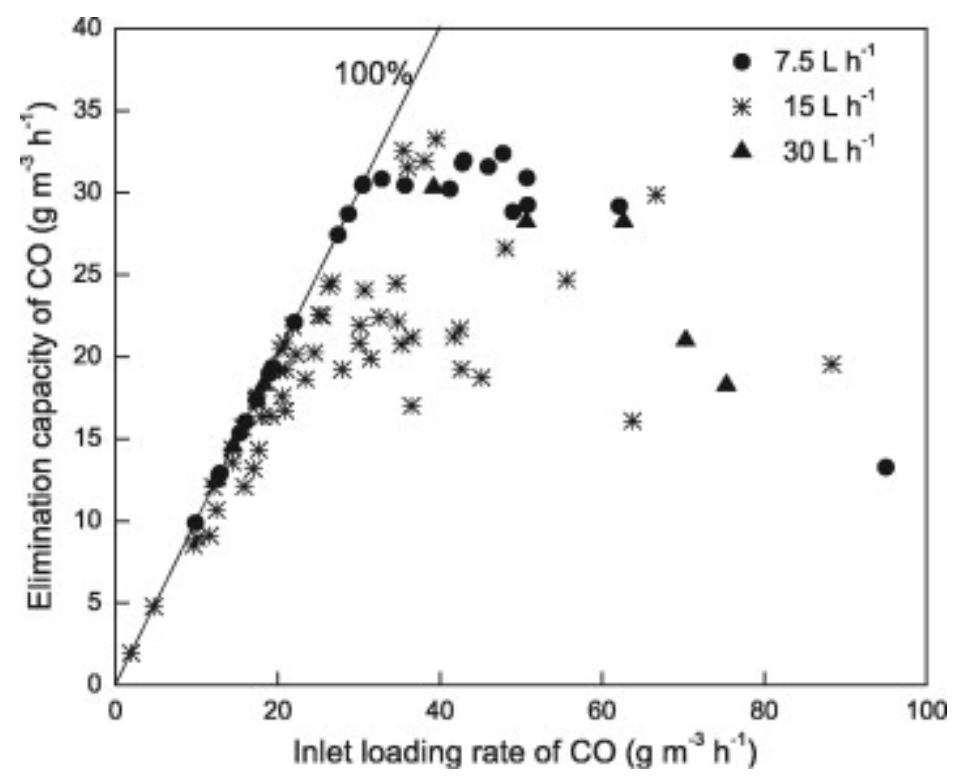

Fig. 5. Elimination capacity of CO and removal efficiency versus inlet loading rate.

The lower maximum elimination capacity reached in the previous studies on CO removal from polluted air (Robra et al., 1997 and Prado et al., 2008) could have been due to factors as the lack of nutrients during the operation, the presence of other pollutants, or to a lower diversity and activity of microorganisms, among others. However, further studies are still needed in order to clearly understand the parameters that allow to maximize CO removal.

Fig. 6 shows the removal efficiency as a function of the inlet $\mathrm{CO}$ concentration at a gas flow rate of $15 \mathrm{~L} \mathrm{~h}^{-1}$, corresponding to an EBRT of $6 \mathrm{~min}$. As expected, a gradual decrease in efficiency was observed as the gas concentration increased. The biofilter reached an efficiency exceeding $94 \%$ when fed less than $1500 \mathrm{mg} \mathrm{CO} \mathrm{m}^{-3}$. When the inlet concentration was increased above this value, the removal efficiency gradually decreased and reached $25 \%$ when the inlet concentration was $6380 \mathrm{mg} \mathrm{m}^{-3}$.

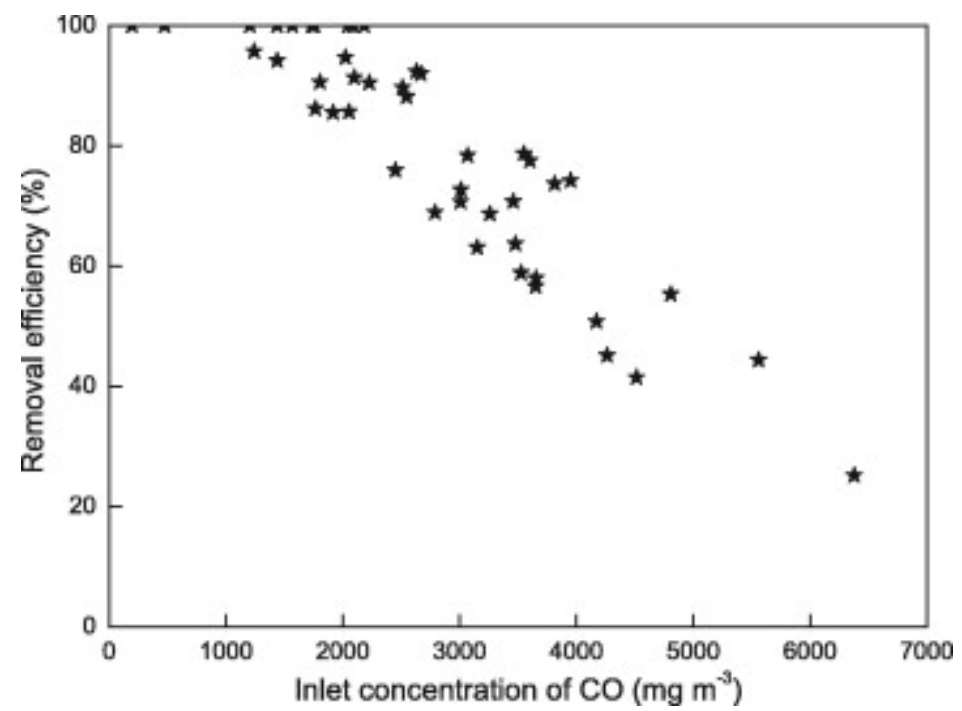

Fig. 6. Changes of removal efficiency with respect to the inlet concentration of CO. 


\subsubsection{Scanning electron microscopy observations}

Samples of the support were withdrawn from the biofilter and observed under SEM. Fig. 7 shows that bacterial rods piled on the surface of both lava rock and peat are the dominant microorganisms. Fig. 7 shows the structure of clean lava rock and peat before inoculation. The particles of both supports were highly heterogeneous with pores, which were sufficiently large to allow colonization by microorganisms. Samples taken from the biofilter after one year operation showed an apparent increase in the biofilter media colonization. Dense microbial morphologies, mainly bacterial colonies on the surface of the peat were observed (Fig. 7). It seems that microorganisms grew on both packing materials after $\mathrm{CO}$ introduction into the biofilter. However, microorganisms preferred to grow in peat instead of lava rock. The surface of lava rock was only fractionally covered by biofilm. These observations also revealed a heterogeneous biofilm, in contrast to the smooth and homogeneous biofilms which have often been assumed in models used to describe the behavior of gas-phase biofilters (Ottengraf and van den Oever, 1983).
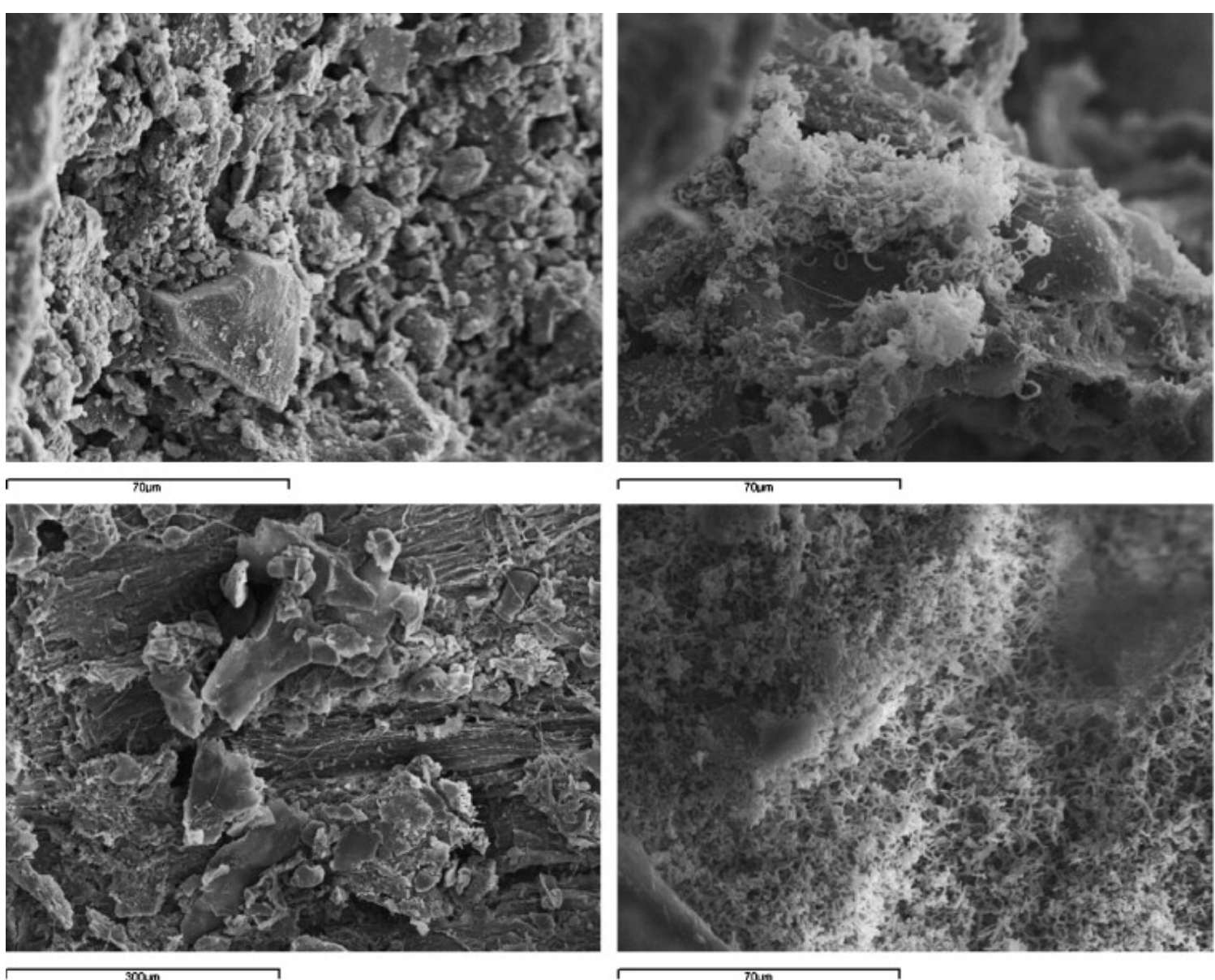

Fig. 7. Scanning electron microphotographs of packing material taken from inside the biofilter.

Top: lava rock. Bottom: peat. Left: fresh packing. Right: used packing. Scale bars represent $70 \mu \mathrm{m}$, except for the bottom-left-figure where it is $300 \mu \mathrm{m}$. 


\section{Conclusions}

The results presented herein prove that CO-polluted air can be treated by means of biological technology. A maximal elimination capacity of $33 \mathrm{~g} \mathrm{CO} \mathrm{m}^{-3} \mathrm{~h}^{-1}$ was obtained in a biofilter packed with the mixture of lava rock and peat, and above $85 \%$ removal efficiency was reached at an inlet gas concentration of $3950 \mathrm{mg} \mathrm{m}^{-3}$, with an EBRT of $3 \mathrm{~min}$. Further work needs to be conducted to optimize the bioreactor performance and determine the economic viability of this new technology. Since CO is often present in mixture with other volatile pollutants, its removal in such mixtures should be studied as well.

\section{Acknowledgement}

The research work of Yaomin Jin and Ling Guo was financially supported by the Xunta de Galicia through project PGIDIT05PXIC10304PN.

\section{References}

Colby et al., 1985

J. Colby, E. Williams, A.P.F. Turner

Applications of CO-utilizing microorganisms

Trends Biotechnol., 3 (1985), pp. 12-17

L. Daniels, G. Fuchs, R.K. Thauer, J.G. Zeikus

Carbon monoxide oxidation by methanogenic bacteria

J. Bacteriol., 132 (1977), pp. 118-126

\section{I.J. Higgins, D.J. Best, R.C. Hammond}

New findings in methane-utilizing bacteria highlight their importance in the biosphere and their commercial potential

Nature, 286 (1980), pp. 561-564

Y. Jin, M.C. Veiga, C. Kennes

Bioprocesses for the removal of nitrogen oxides from polluted air

J. Chem. Technol. Biotechnol., 80 (2005), pp. 483-494

Y. Jin, M.C. Veiga, C. Kennes

Effects of $\mathrm{pH}, \mathrm{CO}_{2}$, and flow pattern on the autotrophic degradation of hydrogen sulfide in a biotrickling filter

Biotechnol. Bioeng., 92 (2005), pp. 462-471

C. Kennes, Y. Jin, M.C. Veiga

Fungal and dechlorinating biocatalysts in waste gas treatment

P. Lens, C. Kennes, P. Le Cloirec, M.A. Deshusses (Eds.), Waste Gas Treatment for

Resource Recovery, IWA Publishing, London, Seattle (2006), pp. 277-301

C. Kennes, F. Thalasso

Waste gas biotreatment technology

J. Chem. Technol. Biotechnol., 72 (1998), pp. 303-319 
C. Kennes, M.C. Veiga

Bioreactors for Waste Gas Treatment

Kluwer Academic Publishers, Dordrecht, Boston (2001)

C. Kennes, M.C. Veiga

Fungal biocatalysts in the biofiltration of VOC-polluted air

J. Biotechnol., 113 (2004), pp. 305-319

E. Küster, R. Locci

Studies on peat and peat microorganisms

Arch. Microbiol., 45 (1963), pp. 188-197

G. Leson, A.M. Winer

Biofiltration: an innovative air pollution control technology for VOC emissions

J. Air Waste Manage., 41 (1991), pp. 1045-1054

P. Li, D.E. Miser, S. Rabiei, R.T. Yadav, M.R. Hajaligol

The removal of carbon monoxide by iron oxide nanoparticles

Appl. Catal., B - Environ., 43 (2003), pp. 151-162

A. Mériaux, P. Pageau, Y. Cormier, N. Goyer, C. Duchaine

Bioaerosols in peat moss processing plants

J. Occup. Environ. Hyg., 3 (2006), pp. 408-417

O. Meyer, H.G. Schlegel

Biology of aerobic carbon monoxide-oxidizing bacteria

Annu. Rev. Microbiol., 37 (1983), pp. 277-310

S.P.P. Ottengraf, A.H.C. van den Oever

Kinetics of organic compounds removal from waste gases with a biological filter

Biotechnol. Bioeng., 25 (1983), pp. 3089-3102

L. Peng, C. Zhao, Y. Lin, X. Zheng, X. Tie, L. Chan

Analysis of carbon monoxide budget in north China

Chemosphere, 66 (2007), pp. 1383-1389

O.J. Prado, M.C. Veiga, C. Kennes

Treatment of waste gases from formaldehyde- and formaldehyde-resin-producing industries

P. Lens, C. Kennes, P. Le Cloirec, M.A. Deshusses (Eds.), Waste Gas Treatment for Resource Recovery, IWA Publishing, London, Seattle (2006), pp. 463-478

O.J. Prado, M.C. Veiga, C. Kennes

Removal of formaldehyde, methanol, dimethylether and carbon monoxide from waste gases of synthetic resin-producing industries

Chemosphere, 70 (2008), pp. 1357-1365 
Robra, K.H., Wellacher, M., Kirchmair, F., Leistentritt, R., Pucher, K., 1997. Abluftreinigung für Straßentunnel und Tiefgaragen durch carboxidotrophe Mischpopulationen. In: Prins, W.L., van Ham, J. (Eds.), Biologische Abgasreinigung (Biological Waste Gas Cleaning): Proceedings of an International Symposium, Maastricht, The Netherlands, Veren. Lucht, VDI Verlag, Düsseldorf, pp. 131-140.

D.R. Tilley, J. Mentzer

Soil uptake of carbon monoxide emitted in the exhaust of a gasoline-powered engine J. Air Waste Manage., 56 (2006), pp. 115-120

J.W. van Groenestijn, P.G.M. Hesselink Biotechniques for air pollution control Biodegradation, 4 (1993), pp. 283-301 